\title{
Episodic but ample sporophyte production in the moss Drepanocladus turgescens (Bryophyta: Amblystegiaceae) in SE Sweden
}

\author{
Lars Hedenäs \& Irene Bisang
}

Episodic but ample sporophyte production in the moss Drepanocladus turgescens (Bryophyta: Amblystegiaceae) in SE Sweden. - Acta Mus. Siles. Sci. Natur., 68: 83-93, 2019.

\begin{abstract}
In the Baltic area, the long-lived dioicous wetland moss Drepanocladus turgescens (T.Jensen) Broth. produces sporophytes rarely and at irregular intervals. Based on surveys of sporophyte occurrences at 13 sites in two regions in northern Gotland (Sweden) during three to five years, we ask: (1) Is sporophyte formation associated with precipitation and a precipitation index that considers the dry periods during July-August of the preceding year, when gametangia are formed and fertilization occurs? (2) Does the estimated spore output suffice for the species' long-term persistence of the (Northern) European population species? In one of the study regions, where D. turgescens occurs in depressions, sporophyte formation was associated with the two precipitation parameters. In the other study region, with relatively higher precipitation and exposed occurrences on a slightly sloping bedrock with very little accumulated soil, no such association existed. We suggest that this lack of weather effects results from that the exposed rock habitat requires longer continuously wet periods than the depression habitat to allow for gametangia initiation and development, and fertilisation. Average spore production for six spore capsules, from three Gotland localities was 181,000. Based on the sporophyte counts during the survey years, we estimated the total reproductive output as 411.5 million spores in 2013, and 42.5 million in 2015, in the two respective study regions. Taken together with data on haplotype patterns and considering observations on recent colonisations, we argue that such a relatively low and episodic regional spore production is sufficient to maintain global populations of long-lived species, even if these occur in specialized and geographically restricted habitats.
\end{abstract}

Key words: Episodic spore production, Habitat, Precipitation, Spore number

\section{Introduction}

The frequency of sporophyte production in mosses varies widely among species and with the species' life histories (During 2007, Longton 1992). For example, rarity of sporophytes is more prevalent in dioicous than in monoicous species (Gemmel 1950, Heegaard 2001). In a few species, sporophytes are virtually unknown, and otherwise the frequency varies from rare to common (Longton 1992). Within species, sporophyte frequency may vary among different regions or ecosystems, or temporally among years and seasons (e.g., Maciel-Silva \& Pereira de Oliveira 2016, Maciel-Silva \& Válio 2011, Sundberg 2002). This variation relates to weather or other environmental conditions in a number of studied species, and the environmental effects may vary among different phases of the species' life cycle (Longton 1990, Stark 2001, 2005, Sundberg 2002).

Mature sporophytes produce and release spores, which in mosses are usually smaller than $20 \mu \mathrm{m}$ and are able to disperse very far (Wilkinson et al. 2012). Dispersal affects not only biogeographical patterns, range expansions and (meta)population dynamics, but also processes at the gene and individual level (Clobert et al. 2012). Gene flow, genetic variability and population differentiation increase the resilience of species when environments change (Frankham et al. 2002, Williams et al. 2008). Dispersal capacities are thus important for addressing many topics of moss biology, including pressing conservation issues, such as predicting a species' response to climate and land-use changes (Corlett \& Westcott 2013). 
Drepanocladus turgescens (T.Jensen) Broth. is a dioicous wetland moss that is rarely reported with sporophytes (Abramova et al. 1961, Hedenäs 2002, Miller 1980), which is substantiated by herbarium records (Fig. 1). In Europe, specimens with sporophytes were collected at a few places during the first 25 years of the 20th century, in Northern Swedish Lappland (1 locality), on the Baltic Sea island Öland in Sweden (4), Väike-Pakri in Estonia (1), and in the surroundings of Vienna in Austria (2) (Hedenäs 2002). At the end of the 20th century, sporophytes were again encountered a few times (LH: Saaremaa, Estonia, 1989; northern Gotland, Sweden, 1996).

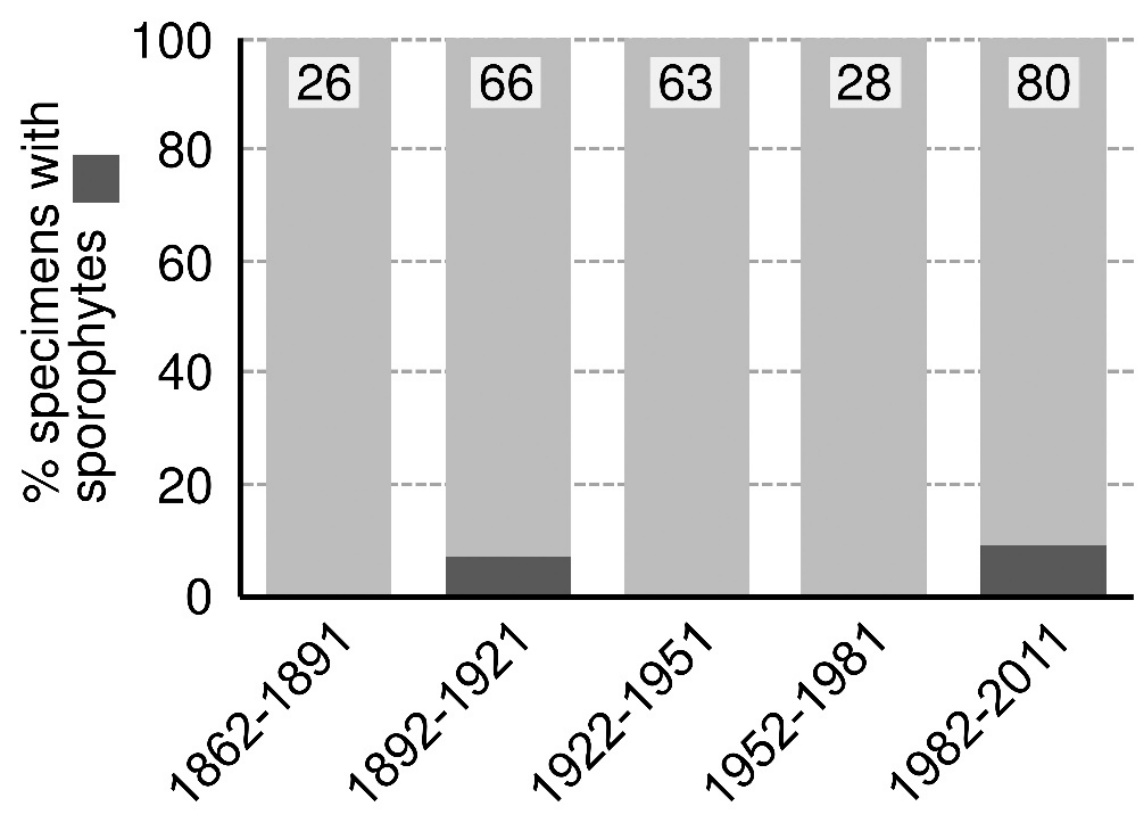

Fig 1: Sporophyte occurrence in 266 Drepanocladus turgescens specimens from Sweden collected between 1836 and 2011 in the holdings of the bryophyte herbarium at S, as to 30-yr periods. The figures in the upper portions of the bars are numbers of examined specimens per period.

During fieldwork for other purposes in 2011 (Hedenäs \& Bisang 2015), we discovered numerous occurrences of $D$. turgescens with abundant sporophyte production on both the Swedish Baltic Sea islands Öland and Gotland. During subsequent years, we observed additional sporophyte occurrences on Gotland. This resulted in a set of twelve sporophyte-bearing sites of D. turgescens in two regions of Gotland, which we repeatedly re-visited three to four times between 2013 and 2018. In this paper, we explore a potential effect of weather conditions on sporophyte formation. Our first exploratory analyses, and that we did not encounter dried-out or aborted sporophytes in the spring, suggested that conditions affecting the fertilization process rather than conditions during the period of sporophyte development are critical. Hence, we here focus on a possible effect of weather conditions on water availability prior to (gametangia maturation) and during the fertilization phase. Further, we quantify the spore output during years of sporophyte production and discuss whether this could potentially be sufficient to maintain the species' current distribution in Europe.

\section{Material and methods}

Study species

Drepanocladus turgescens (Amblystegiaceae) forms large, a few $\mathrm{cm}$ up to $20 \mathrm{~cm}$ long, slightly and irregularly branched, turgid shoots. The species classifies as a 'perennial stayer' in the life strategy system of (During 1979, 1992). It is dioicous, has a tall seta, a cylindrical, curved, orthogonal spore capsule, and the spores are 10-17 $\mu \mathrm{m}$ 
in diameter (Hedenäs 1992). Sporophytes are generally absent or rare, but during 2011-2015 we observed sporophytes at one site on the Finnish island Signilskär (Åland archipelago), and more than twenty on the two main Swedish islands in the Baltic Sea, Öland (8) and Gotland (13). In Europe, D. turgescens is most common in the north, in Svalbard, the Scandinavian mountain range, and in the limestone islands around the Baltic Sea. In addition, it occurs at a few isolated localities in the lowlands of Scandinavia. In Central Europe, including the Alps, its population is fragmented and declining (Hedenäs and Bisang, in press).

In lowland localities of Northern Europe, D. turgescens typically grows on strongly calcareous ground, in depressions that dry out periodically during summer. In mountains and in the far north it occurs also in less strongly calcareous habitats (Birks \& Dransfield 1970, Hedenäs 2002), and in depressions that dry out for shorter periods than in the south. In addition, the species is relatively frequent in habitats with trickling water or along brooklets. In Scandinavia, D. turgescens only rarely grows in permanently wet mires.

\section{Number of sporophytes per studied patch}

We examined in total 13 sites with sporophytes, from two regions in northern Gotland. Nine sites were located in the surroundings of the meteorological station $\mathrm{Ar}$ and four in the surroundings of the meteorological station Hejnum (Table 1). In these, we observed D. turgescens sporophytes in 2011, 2013, or 2015. We repeatedly visited all but one site between three to five times, in late spring to early summer (between 6 May and 12 June). We surveyed all Hejnum sites consecutively from 2015 to 2018, five Ar sites in 2013 and 2016-2018, and three Ar sites in 2013 and 2017-2018. At each site, we surveyed one patch. We defined a patch as a continuous occurrence of $D$. turgescens in a periodically wet depression, with a distance between neighbouring ramets of up to a maximum of $1 \mathrm{~m}$. We estimated the patch size to the nearest $1 \mathrm{~m}^{2}$, or to the nearest $0.25 \mathrm{~m}^{2}$ for patches smaller than $1 \mathrm{~m}^{2}$; $0.25 \mathrm{~m}^{2}$ indicates a patch size of up to this area. We estimated sporophyte numbers in each patch in 2013 and 2015 by counting capsules. In patches with more than ca. 100 capsules, we counted sporophytes in at least two plots of $10 \times 10 \mathrm{~cm}^{2}$, using a frame with a cm-grid, within each of the distinguishable capsule-bearing sub-patch areas. We then estimated the total sporophyte number in the patch based on these counts and the area of the sub-patches in relation to the total patch size.

Tab 1: Study sites on northern Gotland, Sweden: ACRONYM: Site, Lat., Long. (S reg. no. for collected vouchers). Closest to Ar meteorological station:

BUN: Bunge, near limestone kiln W of Bunn, $57.8527^{\circ} \mathrm{N}, 18.9744^{\circ} \mathrm{E}$; HAU1: Fleringe, ca. $400 \mathrm{~m} \mathrm{SW}$ of Hau farm, $57.8922^{\circ} \mathrm{N}, 1^{18.9777^{\circ} \mathrm{E}}(\mathrm{B} 184253$, B196890, B237271); HAU2: Fleringe, ca. $700 \mathrm{~m} \mathrm{SW}$ of Hau farm, $57.8881^{\circ} \mathrm{N}, 18.9742^{\circ} \mathrm{E}$ (B184254, B196892, B23763); KYR1: Fleringe, W end of Kyrkgatmyr, S side, $57.8890^{\circ} \mathrm{N}$, $18.9581^{\circ} \mathrm{E}$ (B196895, B237272); KYR2: Fleringe, middle of Kyrkgatmyr, S side, $57.8892^{\circ} \mathrm{N}, 1^{18.9589^{\circ} \mathrm{E}}$ (B196894, B236513); LAR: Lärbro, ca. $800 \mathrm{~m} \mathrm{SW}$ of Stora Ire, $57.7782^{\circ} \mathrm{N}, 1^{18.8589^{\circ} \mathrm{E}}$ (B196928); STR: Bunge, ca. $500 \mathrm{~m}$ E of Strå, $57.8791^{\circ} \mathrm{N}, 19.0071^{\circ} \mathrm{E}$ (B184252, B196888, B237635); TVA1: Fleringe, ca. $1.6 \mathrm{~km}$ WSW of Tvärlingsmyr, $57.8702^{\circ} \mathrm{N}, 1^{18.9199^{\circ} \mathrm{E}}$ (B196905); TVA2: Fleringe, ca. $1.6 \mathrm{~km} \mathrm{WSW}$ of Tvärlingsmyr, 57.8702 $\mathrm{N}$, $18.9186^{\circ} \mathrm{E}(\mathrm{B} 196906)$.

\section{Closest to Hejnum meteorological station:}

HEJ1: Hejnum, Hejnum hällar, $1.5 \mathrm{~km} \mathrm{NE}$ of Graute, $57.6778^{\circ} \mathrm{N}, 18.6596^{\circ} \mathrm{E}(\mathrm{B} 222088$, B238801); HEJ2: Hejnum, Hejnum hällar, $1.5 \mathrm{~km}$ NE of Graute, $57.6782^{\circ} \mathrm{N}, 18.6592^{\circ} \mathrm{E}(\mathrm{B} 222089, \mathrm{~B} 238802)$; HEJ3: Hejnum, Hejnum hällar, $1.5 \mathrm{~km} \mathrm{NE}$ of Graute, $57.6787^{\circ} \mathrm{N}, 1^{18.6617^{\circ} \mathrm{E}}$ (B222091, B238803); HEJ4: Hejnum, Hejnum hällar, $1.5 \mathrm{~km} \mathrm{NE}$ of Graute, $57.6782^{\circ} \mathrm{N}, 18.6641^{\circ} \mathrm{E}$ (B222092, B238804).

\section{Relationship between sporophyte production and habitat wetness}

In D. turgescens sex organs mature, and fertilization takes place during late summer, from the second half of August (Arnell 1875), and embryos develop into sporophytes in the following late spring to early summer (own observations). Based on preliminary exploratory analyses and the lack of observed dried-out capsules in late spring, we argue that conditions affecting the initiation and development of sexual organs and the fertilization process are likely to be critical for sporophyte occurrence. We therefore investigated the effect of the precipitation and its temporal distribution during July-August in the year before the sporophyte observations.

We downloaded precipitation data for the two meteorological stations $\operatorname{Ar}\left(57.9168^{\circ} \mathrm{N}, 18.9569^{\circ} \mathrm{E}\right)$ and Hejnum $\left(57.6954^{\circ} \mathrm{N}, 18.6377^{\circ} \mathrm{E}\right)$ from the Swedish Meteorological and Hydrological Institute (SMHI; https://opendata-download-metobs.smhi.se/explore/?parameter =3; accessed 1 April 2018). These stations are located close to the two respective study regions with occurrences of $D$. turgescens sporophytes. For each year prior to the field observations and for the two meteorological stations separately, we computed the total precipitation amount for July and August. We also calculated a Precipitation Index (PI) that takes into account the number of days without precipitation. Successive dry days increase the likelihood that patches dry out (Stark 2005), which impedes successful fertilization. PI is the total amount of precipitation during July and August 
(P, mm) divided with the number of days during July and August with at least $1 \mathrm{~mm}$ precipitation (A) minus the number of days with $<1 \mathrm{~mm}$ precipitation $(\mathrm{B})$ : $\mathrm{PI}=\mathrm{P} /(\mathrm{A}-\mathrm{B})$. $(\mathrm{A}-\mathrm{B})$ was negative for all study years, indicating fewer rainy than dry days during this period. A more strongly negative PI for a certain year indicates more favourable moisture conditions, (i. e., relatively few dry days that counteract the moistening effect of precipitation).

\section{Spore counts and spore output estimates}

We estimated spore numbers per capsule in six capsules, two from each of three specimens collected in the study regions on Gotland (Bunge, E of Strå, $57.8791^{\circ} \mathrm{N}, 19.0071^{\circ} \mathrm{E}, 2011$; S, reg. no. B184252; Fleringe, Kyrkgatmyr, 57.8892 ${ }^{\circ} \mathrm{N}, 18.9589^{\circ} \mathrm{E}, 2013$; S, reg. no. B196894; Hejnum, Hejnum hällar, 57.6782 ${ }^{\circ} \mathrm{N}, 1^{18.6592^{\circ}}$ E, 2015; S, reg. no. B222089). We selected ripe, but undehisced capsules, and made all spore counts on 30 October 2018.

Under a dissecting scope, we opened each capsule separately in $5 \mathrm{ml}$ deionized water with a minute amount of detergent to facilitate spore clump disintegration. We first shook the water-spore-capsule wall mixture for 30 sek on a Vortex Genie ${ }^{\circledR} 2$ (Scientific Industries) at a shaking speed of 3.5. We then examined the mixture under the dissecting scope, picked out capsule wall pieces clean of spores, and 'crushed' remaining visible spore clumps with a fine pair of forceps. We shook the mixture for another $30+60$ sek on the Vortex to disperse the spores thoroughly in the water. Immediately thereafter, we took a $1 \mathrm{ml}$ subsample and placed this in a Gridded Sedgewick Rafter (Wildco®, Model \#1801-G20), with a $1 \mathrm{ml}$ cell volume. The counting chamber has a 20 x 50 square grid, and thus each grid cell has a volume of $1 \mu 1$. We counted spore numbers in ten randomly selected (www.random.org; accessed 29 October 2018) grid cells, and multiplied the mean spore number per grid cell with 5000 to estimate the total spore number per capsule.

\section{Results}

Number of sporophytes produced

Out of 13 patches with observed sporophyte production during at least one year (Fig. 2, Table 1), we monitored 12 during 3-4 years between 2013 and 2018. In three of these sites, we had encountered sporophytes already in 2011 , but we did not perform any counts in that year.

During 2013, the estimated sporophyte production in the studied sites of the Ar region was 2,274 (Table 2). It varied from 11 to 1,898 sporophytes per patch, with $83 \%$ of the capsules in one single patch (STR, Table 1). Estimated sporophyte density ranged from 0.7 to 38 sporophytes per $\mathrm{m}^{2}$ patch area. The estimated sporophyte production in the Hejnum region in 2015 was 235 sporophytes (Table 2), varying from 23 to 100 sporophytes per patch. Sporophyte density was between 11 and 320 sporophytes per $\mathrm{m}^{2}$. We found the highest density in a small patch of $0.25 \mathrm{~m}^{2}$.

Tab 2: Observations of patch size, Drepanocladus turgescens cover, and total numbers of sporophytes at D. turgescens patches in 2013 or 2015; sporophyte numbers based on field counts (see Material and Methods). Site acronyms are explained in Table 1.

\begin{tabular}{lcccc}
\hline $\begin{array}{l}\text { Site } \\
\text { acronym }\end{array}$ & $\begin{array}{c}\text { Observation } \\
\text { date }\end{array}$ & $\begin{array}{c}\text { Patch size, } \\
\mathrm{m}^{2}\end{array}$ & $\begin{array}{c}\text { D. turgescens } \\
\text { cover, } \%\end{array}$ & $\begin{array}{c}\text { Total no. } \\
\text { of sporophytes }\end{array}$ \\
\hline STR & 11 May 2013 & 50 & 20 & 1898 \\
HAU1 & 11 May 2013 & 14 & 20 & 22 \\
HAU2 & 11 May 2013 & 30 & 10 & 84 \\
KYR1 & 11 May 2013 & 40 & 15 & 91 \\
KYR2 & 12 May 2013 & 78 & 10 & 74 \\
BUN & 12 May 2013 & 22 & 5 & 11 \\
TVA1 & 12 May 2013 & 12 & 10 & 21 \\
TVA2 & 12 May 2013 & 142 & 10 & 62 \\
LAR & 13 May 2013 & 16 & 10 & 11 \\
HEJ1 & 16 May 2015 & 3 & 70 & 23 \\
HEJ2 & 16 May 2015 & 0.25 & 70 & 100 \\
HEJ3 & 16 May 2015 & 1 & 70 & 80 \\
HEJ4 & 16 May 2015 & 0.25 & 70 &
\end{tabular}



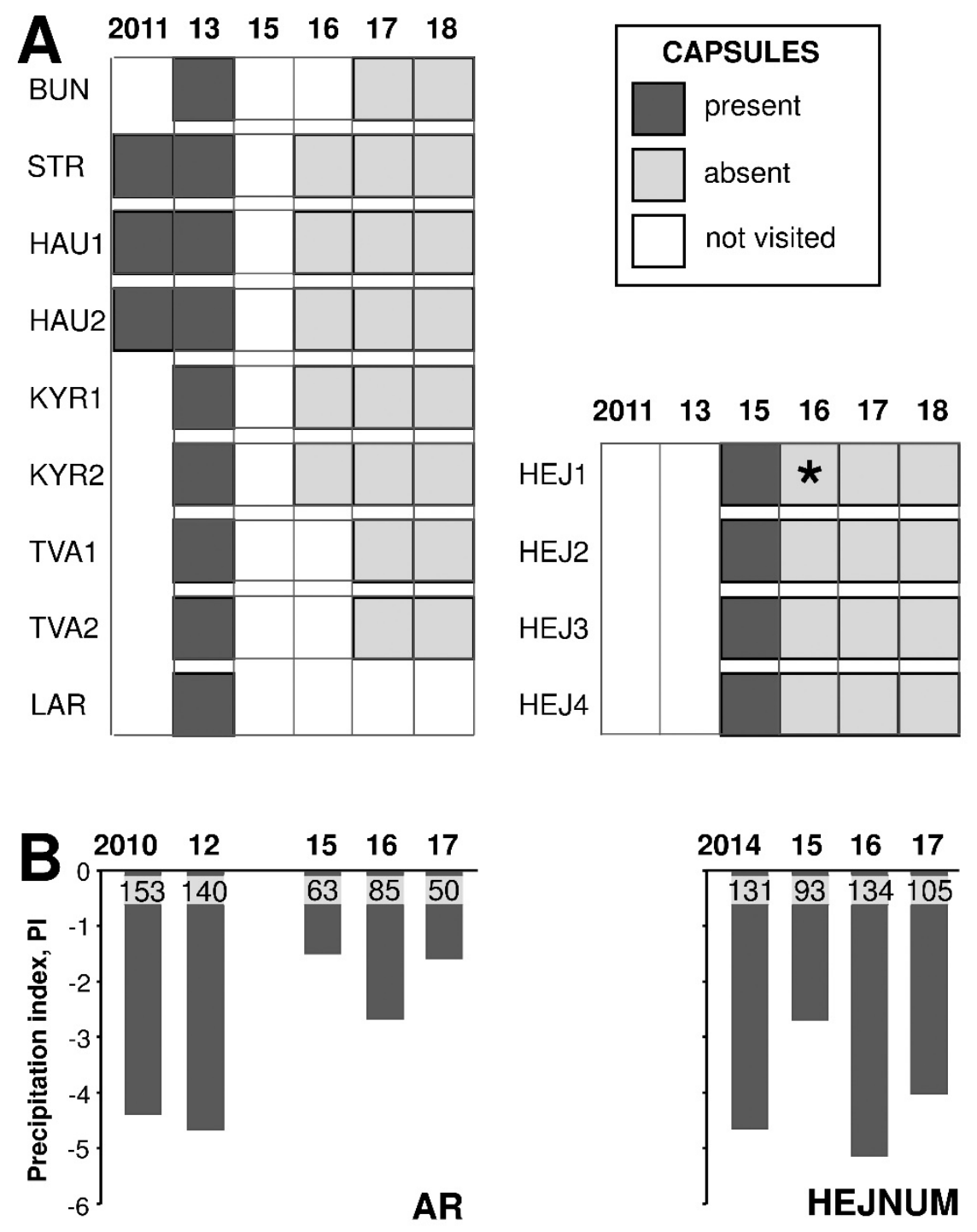

Fig 2: (A) Observations of Drepanocladus turgescens sporophytes at 13 sites on northern Gotland between 2011 and 2018. Dark grey, sporophytes present; light grey, sporophytes absent; white, site not surveyed. (B) Precipitation index (PI) and total precipitation in July and August ( $\mathrm{mm}$, base of bars) in the years preceding the survey years. Acronyms for the sites are explained in Table 1.

\section{Sporophyte production and habitat wetness}

Sporophyte occurrence per patch and year is depicted in Fig. 2A. Figure 2B displays the PI and total precipitation ( $\mathrm{mm}$ ) for July plus August, for the years prior to the sporophyte survey. Total precipitation was considerably higher in Hejnum than in Ar from 2015 to 2017 (147 to $210 \%$ ). PI and precipitation amount co-varied with the presence of sporophytes in the following year in Ar, but not in Hejnum.

\section{Number of spores produced}

Spore number per studied spore capsule varied between 116,500-348,000, with a mean of 181,000 spores per capsule (Appendix 1). Based on the sporophyte counts in 2013 from the Ar region and 2015 from the Hejnum region, this results in an annual total reproductive output in northern Gotland of 411.5 and 42.5 million spores, respectively. 


\section{Discussion}

We noted sporadic but partly extensive sporophyte formation in the wetland moss $D$. turgescens that was regionally associated with moisture conditions during the summer months preceding the capsule observations. Reproductive output in terms of spore numbers was considerable during years with sporophyte production.

\section{Sporophyte production and habitat wetness}

Gametangia formation and fertilisation in bryophytes were associated with rainfall or patch hydration in several studies from different climatic areas (Maciel-Silva \& Pereira de Oliveira 2016, Maciel-Silva \& Válio 2011, Pereira et al. 2016, Stark 2005, Sundberg 2002). For D. turgescens, we found that sporophyte occurrence was related to wetness during the period of gametangia formation and fertilization in the Ar area. This held true for both wetness measures, i.e. the total precipitation and the precipitation index (PI) for July and August during the year prior to sporophyte maturation (Fig. 2). Beyond summer rainfall amount, PI takes also into account the relative numbers of days with and without precipitation. Consecutive dry days will lead to patch dehydration (Stark 2005), which may result in drought stress during gametangia formation, or may inhibit spermatozoid movement. Although moss antheridia, sperms and embryonic sporophytes have been shown in laboratory experiments to be tolerant to desiccation under certain conditions of dehydration (Döbbeler 2017, Shortlidge et al. 2012, Stark \& Brinda 2015), it is expected that extended periods of substrate drought negatively impact the development of gametangia, sporophytes, as well as sperm motility.

In the Hejnum region, sporophyte occurrence was unrelated to precipitation data in the previous year (Fig. 2). The D. turgescens sites' topography and habitat differ between the Ar and Hejnum regions, which may explain this discrepancy. Sundberg (2002) showed that Sphagnum reproduction in different habitats may respond differently to similar weather conditions. The precipitation in Hejnum is 1.5-2 times higher than in Ar. Intuitively we would therefore expect sporophyte production during some years when patches in the Ar area are too dry. However, the patches in Hejnum occur on gently sloping, exposed rock (Fig. 3A), whereas those in Ar are either located in periodically wet depressions (Fig. 3B) or bordering Cladium fens, which in turn occupy very large depressions that stay wet or moist during long periods (Fig. 3C). At the Hejnum sites, water likely seeps over the rocks during rain showers and accumulates briefly in very shallow depressions or disappears into narrow vegetation strips along fissures. At the AR sites, on the other hand, water accumulates from rain falling directly into the depressions inhabited by $D$. turgescens or water moves into the depressions from the immediate surroundings. We suggest that the Hejnum sites, on exposed rock with at most very little or no soil, are more sensitive to dry spells than the Ar sites, where water evaporates more slowly from the depressions after rainfall. To explore this possibility further, detailed monitoring of patch moisture with data loggers during the period critical for gametangia formation and fertilization is required.

Sporophytes number per patch varied between 11 and 100, except for a single patch with almost 1,900 capsules. The predominance of patches with relatively few sporophytes agrees with our observations from Öland, Åland, and Estonia. The outstanding patch at STR in the Ar region was situated at the margin of a Cladium fen (Fig. 3C). However, similarly sized patches at KYR1 and KYR2 also bordered a Cladium fen, so fen proximity cannot be the only explanation for the high sporophyte number at this site.

Weather conditions can influence different stages of bryophyte reproduction, possibly depending on the habitat and involving different mechanisms (Sundberg 2002). Both extended droughts and heavy rainfalls may cause widespread sporophyte abortion during some years, which severely reduces the number of mature sporophytes (Stark 2001). Fertilization occurs during late summer in D. turgescens. With one exception (Fig. 2), we never observed aborted 
sporophytes from the previous year during 2016 to 2018. We could have missed abortions during the embryonic stage of the sporophyte (Stark 2002). Such abortions would also have resulted from unsuitable conditions around the time of fertilization, which was the period we scored for effects on sporophyte formation. Later sporophyte abortion would be expected if weather parameters from autumn to the following spring, rather than during late summer, would be critical in explaining mature sporophyte presence.

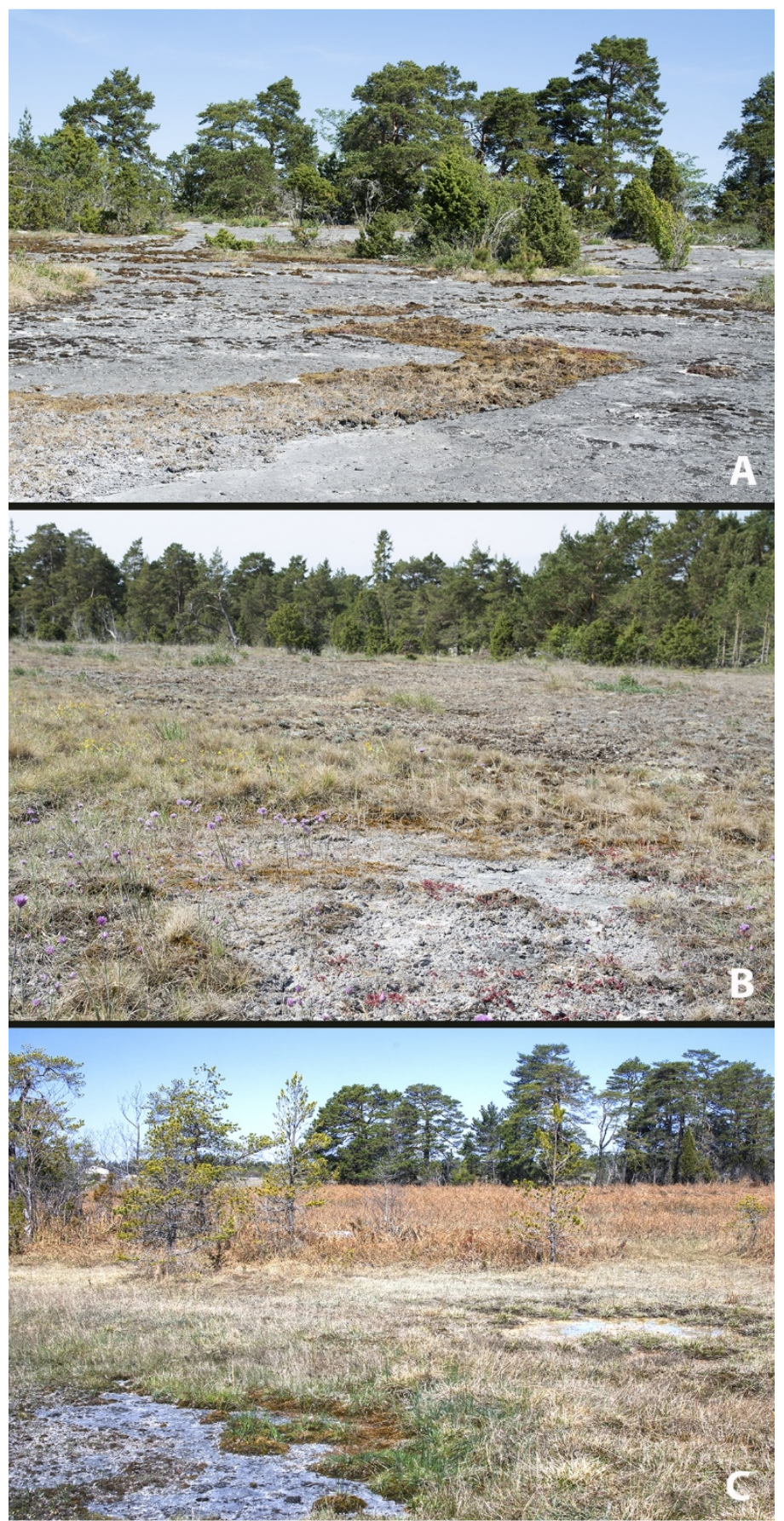

Fig 3: Drepanocladus turgescens habitats with found sporophytes from the two study regions Hejnum and $\mathrm{Ar}$ on northern Gotland. (A) Gently sloping rock with very little soil at the Hejnum site HEJ3. (B) Small depression at the Ar site HAU1. (C) Cladium fen margin at the AR site STR. Site abbreviations as in Table 1. Photos by L. Hedenäs $(\mathrm{A}, \mathrm{B})$ and I. Bisang $(\mathrm{C})$. 
Finally, other factors than the wetness per se may be responsible for the differences in sporophyte formation between the Hejnum and Ar regions. Temperature, light intensity, and photoperiod have been shown to influence sex organ initiation (Chopra \& Bhatla 1983, Hohe et al. 2002), and gametophyte size or spatial distribution of sex organ may affect sporophyte production (Rydgren \& Økland 2002). Such factors and their role in realized sexual reproduction in $D$. turgescens deserve further attention.

\section{Significance of spore output}

The estimated average of 181,000 spores per D. turgescens capsule compares to numbers per capsule in other ground-living pleurocarpous mosses, such as Brachythecium rutabulum (Hedw.) Schimp. and Pleurozium schreberi (Brid.) Mitt. (Longton 1997). The wide variation in spore numbers per capsule, 116,500-348,000, is also consistent with finds in other studies, where the variation has been associated with capsule size variation (Sundberg \& Rydin 1998).

During successful years of realised sexual reproduction, D. turgescens produces at most 40-400 million spores from the study patches on northern Gotland. These are maximum values for these patches, since all observed sporophytes are unlikely to mature. During our survey periods in the spring, some of the counted capsules had not yet reached maturity. Nevertheless, we have reasons to believe that the total spore output in the Baltic Sea area during the survey years was higher than these figures. First, our study sites are obviously a sample of the total sporophytic population in the area. We did not re-visit all Gotland sites with known sporophyte occurrences, and we could not systematically screen all additional $D$. turgescens localities on Gotland and other Baltic areas with potential sporophyte production. Secondly, we encountered sporophytes at other places around the Baltic Sea during the survey years, in 2011 and 2015 at several sites on Öland and in 2013 at one on Signilskär (Åland archipelago). At the latter site, we also noticed sporophytes in the related Drepanocladus trifarius (F.Weber \& D.Mohr) Broth. in a habitat similar to that of D. turgescens. Drepanocladus trifarius is another wetland moss that rarely produces capsules (Bisang et al. 2014). We presume that suitable conditions for sporophyte production occurred widely in the Baltic area during these years and that total reproductive output in $D$. turgescens was considerable in the area.

Many terrestrial pleurocarpous mosses are 'perennial stayers' sensu During $(1979,1992)$, characterized by prevailing clonal expansion, long life span and relatively low reproductive effort. Compared to poor competitors like, e.g., Orthodontium lineare Schwägr. ('colonist' life strategy), total spore output in D. turgescens is low. Orthodontium lineare produced altogether 3.5 billion spores during one year in only twelve sites in southern Sweden (Hedenäs et al. 1989). In Discelium nudum (Dicks.) Brid. with an 'annual shuttle' life strategy, a single large colony may produce 125-175 million spores annually (Lönnell et al. 2012). For D. turgescens the question is whether the erratic and over time relatively low spore output is sufficient to maintain its European population, including an adequate intraspecific genetic variation (Hedenäs 2016), and to allow colonization of appropriate unfilled habitats. On Gotland, for example, the species occurs also in relatively recent wheel-tracks on alvar-ground, which implies that, currently, colonization takes place now and then. In open terrain, and over relatively short distances, this could be accomplished by wind-blown apical buds that detach easily from the shoots (Hedenäs 1992). Indirect evidence from haplotype variation in D. turgescens suggests that the species can establish at suitable localities far from extant occurrences, evidently resulting from spore dispersal. The haplotypes of two populations that occur in land rise areas ( $\AA$ land, Finland; Gästrikland, Sweden) that have been available for colonization for at most 250-500 years, agree with a colonization by spores from localities further south in the Baltic Sea region (Hedenäs 2014). We conclude that episodic sporophyte production and a relatively low spore output suffice to maintain the European and, considering the similar sporophyte frequency in North American D. turgescens (Miller 1980), probably its global population. Our observations on $D$. turgescens can probably be extrapolated to other long-lived perennial mosses with rare or very 
rare sporophyte production and with wide continental or global distributions, such as Calliergon megalophyllum Mikut., Calliergonella lindbergii (Mitt.) Hedenäs, Dichelyma capillaceum (Dicks.) Myrin, Entodon concinnus (De Not.) Paris, Hamatocaulis vernicosus (Mitt.) Hedenäs, Rhytidium rugosum (Hedw.) Kindb., and Sarmentypnum trichophyllum (Warnst.) Hedenäs. Several of these grow in special habitats with restricted distributions. We therefore suggest that widespread long-lived perennial mosses with specialised habitat requirements can maintain genetic diversity and persist in the long term, also when sporophyte production is rare and erratic.

\section{Future perspectives}

The available data suggest that the levels of sexual reproduction and spore dispersal have so far been sufficient for the long-term survival of the European D. turgescens population, but the ongoing climate change may alter this. A recent increase in fertility in British Lunularia cruciata (L.) Lindb. (Blackstock 2018), altered growth and reproductive performance of Polytrichastrum alpinum (Hedw.) G.L.Smith on the Antarctic Peninsula (Shortlidge et al. 2017), and bryophyte distribution shifts in mountain areas (Bergamini et al. 2009, Patiño et al. 2016), were suggested to result from climate change. They indicate that a changed climate will influence the performance of many bryophyte species. We argue that the negative influence will probably be strongest for species that grow in habitats that are close to what bryophytes can tolerate in the long-term in terms of temperature, low precipitation or low humidity, factors that negatively affect bryophyte growth (Proctor 2011). High temperatures and lowered water levels will be especially crucial for wetland species (Glime 2011) like D. turgescens. The species occurs at many sites on the alvar of Öland and on Gotland in habitats with limited water availability, not only during the fertilisation period. At some of the surveyed sites, we observed considerable decreases in patch size or cover of D. turgescens between years with and without sporophytes. Climate models forecast that spring and summer precipitation will increase on Gotland until the end of the 21st century (Persson et al. 2015), suggesting more favourable conditions for $D$. turgescens growth and sexual reproduction. Concurrently, a predicted temperature increase will counteract the higher precipitation and lead to generally drier conditions, longer drought periods during summer, and increased evaporation. This will negatively affect both the abundance and fertility of D. turgescens.

Acknowledgements: We thank Bodil Cronholm, Swedish Museum of Natural History, and Kristoffer Hylander, Stockholm University, for assistance with laboratory equipment.

\section{References}

Abramova A.L.A., Savicz-Ljubitskaja L.I. \& Smirnova Z.N. (1961): Opredelitel listostebelnich mchov arktiki SSSR. Moskva: Izdatelstvo Akademii Nauk SSSR, 714 pp.

Arnell H.W. (1875): De Skandinaviska löfmossornas kalendarium (PhD thesis). Upsala: Esaias Edquists boktryckeri, 129 pp.

Bergamini A., Ungricht S. \& Hofmann H. (2009): An elevational shift of cryophilous bryophytes in the last century - an effect of climate warming? - Diversity and Distributions 15: 871-879.

Birks H.J.B. \& Dransfield J. (1970): A note on the habitat of Scorpidium turgescens (T. Jens.) Loeske in Scotland. - Transactions of the British Bryological Society 6: 129-132.

Bisang I., Ehrlén J., Perss on C. \& Hedenäs L. (2014): Family affiliation, sex ratio and sporophyte frequency in unisexual mosses. - Botanical Journal of the Linnean Society 174: 163-172.

Blackstock T.H. (2018): Apparent increase in fertility of Lunularia cruciata (L.) Lind. (Marchantiophyta) in Britain associated with climate change. - Journal of Bryology 40: 377-383.

Chopra R.N. \& Bhatla S.C. (1983): Regulation of gametangial formation in bryophytes. - Botanical Review 49: 29-63.

Clobert J., Baguette M., Benton T.G. \& Bullock J.M. (2012): Dispersal ecology and evolution. Oxford: Oxford University Press, XXXIII + 462 pp. 
Corlett R.T. \& Westcott D.A. (2013): Will plant movement keep up with climate change? - Trends in Ecology and Evolution 28: 482-488.

During H.J. (1979): Life strategies of bryophytes, a preliminary review. - Lindbergia 5: 2-18.

- (1992): Ecological classification of bryophytes and lichens. In: B ates J.W. \& Farmer A.M. (ed.), Bryophytes and lichens in a changing environment: 1-31. Oxford: Clarendon Press.

- (2007): Relations between clonal growth, reproduction and breeding system in the bryophytes of Belgium and The Netherlands. - Nova Hedwigia, Beiheft 131: 133-145.

Döbbeler P. (2017): Antheridia of Bryum capillare release moving spermatozoids after two months in the airdry state. - Herzogia 30: 501-503.

Frankham R., Ballou J.D. \& Briscoe D.A. (2002): Introduction to conservation genetics. Cambridge: Cambridge University Press, $617 \mathrm{pp}$.

Gemmel A.R. (1950): Studies in the Bryophyta: 1. The influence of sexual mechanism on varietal production and distribution of British Musci. - New Phytologist 49: 64-71.

Glime J.M. (2011): Ecological and physiological effects of changing climate on aquatic bryophytes. In: Tuba Z., Slack N.G. \& Stark L.R. (ed.), Bryophyte ecology and climate change: 93-114. Cambridge: Cambridge University Press.

Hedenäs L. (1992): The genus Pseudocalliergon in northern Europe. - Lindbergia 16: 80-99.

- (2002): Korvgulmossa Pseudo-calliergon turgescens, en spännande mossa i våra kalkrikaste trakter. - Svensk Botanisk Tidskrift 96: 29-40.

- (2014): Intraspecific genetic variation in selected mosses of Scandinavian interglacial refugia suggests contrasting distribution history patterns. - Botanical Journal of the Linnean Society 176: 295-310.

- (2016): Intraspecific diversity matters in bryophyte conservation - internal transcribed spacer and $r p l 16 \mathrm{G} 2$ intron variation in European mosses. - Journal of Bryology 38: 173-182.

Hedenäs L. \& Bisang I. (2015): Infraspecific diversity in a spore-dispersed species with limited distribution range. - Systematics and Biodiversity 13: 17-27.

- (2019, in press): Are the remains of the Central European population of Drepanocladus turgescens genetically distinct from Scandinavian populations? - Herzogia.

Hedenäs L., Herben T., Rydin H. \& Söderström L. (1989): Ecology of the invading moss species Orthodontium lineare in Sweden: Spatial distribution and population structure. - Holarctic Ecology 12: 163-172.

Heegaard E. (2001): Environmental relationships of perichaetial and sporophyte production in Andreaea spp in western Norway. - Journal of Bryology 23: 97-108.

Hohe A., Rensing S.A., Mildner M., Lang D. \& Reski R. (2002): Day length and temperature strongly influence sexual reproduction and expression of a novel MADS-Box gene in the moss Physcomitrella patens. - Plant Biology 4: 595-602.

Longton R.E. (1990): Sexual reproduction in bryophytes in relation to physical factors of the environment. In: Chopra R.N. \& Bhatla S.C. (ed.), Bryophyte development: Physiology and biochemistry: 139-166. Boca Raton, Florida: CRC.

- (1992): Reproduction and rarity in British mosses. - Biological Conservation 59: 89-98.

- (1997): Reproductive biology and life-history strategies. - Advances in Bryology 6: 65-101.

Lönnell N., Hylander K., Jonsson B.G. \& Sundberg S. (2012): The fate of the missing spores - patterns of realized dispersal beyond the closest vicinity of a sporulating moss. - PLoS ONE 7: e41987.

Maciel-Silva A.S. \& Pereira de Oliveira M. (2016): How tropical moss sporophytes respond to seasonality: Examples from a semi-deciduous ecosystem in Brazil. - Cryptogamie, Bryologie 37: 227-239.

Maciel-Silva A.S. \& Válio I.F.M. (2011): Reproductive phenology of bryophytes in tropical rain forests: the sexes never sleep. - Bryologist 114: 708-719.

Miller N.G. (1980): Mosses as paleoecological indicators of lateglacial terrestrial environments: some North American studies. - Bulletin of the Torrey Botanical Club 107: 373-391.

Patiño J., Mateo R.G., Zanatta F., Marquet A., Aranda S.C., Borges P.A.V., Dirkse G., Gabriel R., Gonzalez-Mancebo J.M., Guisan A., Muñoz J., Sim-Sim M. \& Vanderpoorten A. (2016): An elevational shift of cryophilous bryophytes in the last century - an effect of climate warming? - Scientific Reports 6: 29156.

Pereira M.R., Dambros C.S. \& Zartman C.E. (2016): Prezygotic resource-allocation dynamics and reproductive trade-offs in Calymperaceae (Bryophyta). - American Journal of Botany 103: 1838-1846.

Persson G., Asp M., Berggreen-Clausen S., Berglöv G., Björck E., Axén Mårtensson J., Nylén L., Ohlsson A., Persson H. \& Sjökvist E. (2015): Framtidsklimat i Gotlands län - enligt RCP-scenarier. Klimatologi 31: 1-61.

Proctor M.C.F. (2011): Climatic responses and limits of bryophytes: comparisons and contrasts with vascular plants. In: Tuba Z., Slack N.G. \& Stark L.R. (ed.), Bryophyte ecology and climate change: 35-54. Cambridge: Cambridge University Press. 
Rydgren K. \& Økland R.H. (2002): Sex distribution and sporophyte frequency in a population of the clonal moss Hylocomium splendens. - Journal of Bryology 24: 207-214.

Shortlidge E.E., Eppley S.M., Kohler H., Rosenstiel T.N., Zuniga G.E. \& Casanova-Katny A. (2017): Passive warming reduces stress and shifts reproductive effort in the Antarctic moss, Polytrichastrum alpinum. - Annals of Botany 119: 27-38.

Shortlidge E.E., Rosenstiel T.N. \& Eppley S.M. (2012): Tolerance to environmental desiccation in moss sperm. - New Phytologist 194: 741-750.

Stark L.R. (2001): Widespread sporophyte abortion following summer rains in Mojave Desert populations of Grimmia orbicularis. - Bryologist 104: 115-125.

- (2002): Phenology and its repercussions on the reproductive ecology of mosses. - Bryologist 105: 204-218.

- (2005): Phenology of patch hydratation, patch temperature and sexual reproductive output over a four-year period in the desert moss Crossidium crassinerve. - Journal of Bryology 27: 231-240.

Stark L.R. \& Brinda J.C. (2015): Developing sporophytes transition from an inducible to a constitutive ecological strategy of desiccation tolerance in the moss Aloina ambigua: effects of desiccation on fitness. Annals of Botany 115: 593-603.

Sundberg S. (2002): Sporophyte production and spore dispersal phenology in Sphagnum: the importance of summer moisture and patch characteristics. - Canadian Journal of Botany 80: 543-556.

Sundberg S. \& Rydin H. (1998): Spore number in Sphagnum and its dependence on spore capsule size. Journal of Bryology 20: 1-16.

Wilkinson D.M., Koumoutsaris S., Mitchell E.A.D. \& Bey I. (2012): Modelling the effect of size on the aerial dispersal of microorganisms. - Journal of Biogeography 39: 89-97.

Williams S.E., Shoo L.P., Isaac J.L., Hoffmann A.A. \& Langham G. (2008): Towards an integrated framework for assessing the vulnerability of species to climate change. - PLOS Biology 6: e325 (2621-2626).

Appendix 1. Spore counts in the ten $1 \mu 1$ cells of the Gridded Sedgewick Rafter, and estimated spore numbers per capsule. Two spore capsules were studied for each of three specimens. Further information on the origin of the specimens is provided in the text. Mean numbers of spores (with standard deviations) and estimated spore numbers per capsule are provided in the bottom of the table.

\begin{tabular}{lcccccc}
\hline \multicolumn{7}{c}{ Specimen (S reg. no) and capsule number (1 or 2) } \\
\hline & \multicolumn{7}{c}{ B222089 } & $\mathbf{1}$ & $\mathbf{1}$ & \multicolumn{3}{c}{ B196894 } \\
\hline Grid cell 1 & 34 & 19 & 24 & 27 & 21 & $\mathbf{2}$ \\
Grid cell 2 & 24 & 25 & 11 & 47 & 31 & 46 \\
Grid cell 3 & 22 & 19 & 21 & 34 & 29 & 95 \\
Grid cell 4 & 27 & 22 & 25 & 42 & 41 & 72 \\
Grid cell 5 & 29 & 25 & 15 & 46 & 36 & 72 \\
Grid cell 6 & 21 & 30 & 46 & 45 & 41 & 89 \\
Grid cell 7 & 14 & 25 & 26 & 45 & 33 & 74 \\
Grid cell 8 & 33 & 16 & 27 & 39 & 26 & 58 \\
Grid cell 9 & 26 & 26 & 33 & 56 & 27 & 71 \\
Grid cell 10 & 22 & 26 & 19 & 48 & 30 & 58 \\
\hline Mean (S.D.) & $25.2(6.0)$ & $23.3(4.2)$ & $24.7(9.8)$ & $42.9(8.0)$ & $31.5(6.4)$ & $69.6(13.8)$ \\
\hline Spores/capsule & 126,000 & 116,500 & 123,500 & 214,500 & 157,500 & 348,000 \\
\hline
\end{tabular}

Authors' addresses: Lars Hedenäs \& Irene Bisang, Swedish Museum of Natural History,

Department of Botany, Box 50007, SE-104 05 Stockholm, Sweden

e-mail lars.hedenas@nrm.se \& irene.bisang@nrm.se 